\title{
Whose culture is it anyway? Social working within a rural community
}

Pam Smith

Pam Smith is a social worker of 27 years. She has a rural background and has a strong attachment to her family roots. She has worked in both statutory and non-government social work. She is currently a team leader at a Child and Family Support Service in Southland.

\section{Abstract}

When we consider culture one initially thinks of one's ethnic belonging, but culture also relates to historical, social and familial influences resulting in shared values and beliefs by people living within the same physical and often isolated location. This is what defines a rural culture. These beliefs, experiences and conditions need to be recognised by social workers while working with rural families.

This idea of culture is considered within a study held on change in a rural community carried out in Western Southland, New Zealand in 2009. One of the topics explored was the participants' perception of culture. The discussions with these older citizens are explored alongside other recent rural studies and the participants' perception of culture. The social worker's role working within this environment is then explored.

\section{Introduction}

A social worker does not work with an individual in isolation. All people are embedded in the influences of their past, the realities of their present and their expectations of their future. What has gone before is part of their being. Their experiences, and most importantly their family and friends who have touched them in their life journey, impact upon them. These experiences are often shared and become part of the person's culture. These are factors for both people within communities and social workers themselves.

The environment in which one lives often determines a certain lifestyle. Physical isolation from other country areas means that the group of people within an area may rely on each other for not only friendship and support but also for survival. This creates an interaction, an interdependence and a strong resilience. This is important because the impact on modern society by financial decisions made at a global level often does not consider the social wellbeing of rural New Zealanders.

In Aotearoa New Zealand it is necessary to acknowledge and understand the cultures of both Treaty partners. Both Maori and Pakeha, with their own ethnic beliefs and practices, have rural bases, but with urbanisation occurring over the years this has impacted on all to varying degrees. Those of the two ethnic cultures who remain in the rural environment find themselves with a common bond that sometimes draws them together through a necessity 
for survival. External influences from national and local policies and often just the day-to-day practicalities of living within their physical environment, creates a shared understanding and a reliance on each other. Social working with knowledge of these factors is imperative to be able to work with families within the rural communities. Their thoughts and experiences are considered from this 2009 study as well as two other studies undertaken in the same area later in the same year.

\section{The idea of a rural culture}

Culture has been described as being very complex in meaning and understanding (Connolly, Crighton-Hill \& Ward, 2006). One explanation is 'complex attempts by non-elite groups both to make sense of their world and to resist domination by the politically and socially powerful' (Jones, 1984, p. 35, as cited in James \& Saville-Smith, 1989, p.13). Another explanation is 'the total lifestyle of a people... all of the ideas, knowledge, behavior and material objects that they share' (Sullivan \& Thompson, 1984, as cited in James \& Saville-Smith, 1989, p.13). Both of these explanations were found to have validity within the Tuatapere study.

The idea of a rural culture has been addressed by various writers. 'The people and communities of Western Southland have distinct qualities ... another aspect of social diversity is the difference between rural and urban lifestyles' (Taylor, Taylor, \& McCall, 2009, p.10). '... there are traits, lifestyle choices and occupational factors which make rural dwellers a unique group' (Pitt, 2010, p.39). Whether there is a rural culture, and the extent of the difference between rural and urban, is an issue for researchers and academics but not for the rural people. They identify as rural and where they fit on a continuum or polar difference is not an issue for them. They are who they are. To explore what rural means to them we need first to look at the physical location then the shared views and values that define their culture.

\section{Geographical position}

The town in the study is Tuatapere, a small rural town on the southwest corner of the South Island of New Zealand. It is on the Southern Scenic Route, 87 kilometres west of Invercargill on Highway 99. It was once described as a 'hole in the bush', built on the banks of the once mighty Waiau River that flows down from Lake Manapouri out into Te Wae Wae Bay. To the north are the Takitimu mountain ranges, to the west the Princess mountains and to the northeast are the Longwoods hills covered in native bush with some exotics planted. The Longwoods form a ridge along the South Coast from Riverton to the Merrivale valley, 15 kilometres northeast of Tuatapere.

\section{Historical and cultural influences}

The southwestern coastline of Aotearoa New Zealand and the Waiau River spilling out into Te Wae Wae Bay were the travel routes for Ngai Tahu and other visiting iwi. For Maori the rivers were the highways of the South. This was especially so with the Waiau River, which flows through the township of Tuatapere out to the sea nearby. The Takitimu mountains that form a ridge along the southwestern interior were named after a Kahungunu waka that sank in the mouth of the Waiau River. When European immigrants travelled to this far corner during the 1800s and early 1900s there were, however, only a few Maori whanau actually settled in the area. 
The land that was offered for European settlement was purchased from Maori within the Ngai Tahu land purchase. Blocks of Maori land stayed within the hapu and iwi and were managed by them. During the 1800s arranged marriages between prominent Maori wahine and European sea-faring men were instigated by Maori, and land management was part of these arrangements. Descendants are scattered throughout Murihiku, Southland (Miller, 1975; Cormack \& Orwin, 1997).

The majority of the new arrivals to the area at the end of the nineteenth and beginning of the twentieth century were labourers or farmers from Scotland. The attraction of land opening up for settlement and sawmilling in the local forest offered these families new opportunities. The Tuatapere community became a tight-knit community with a strong parochialism. The length of time that whanau and families had been settled in the area were key to the mana and respect given to each other. The values and beliefs were found to be similar between the whanau, hapu, iwi and kith, kin and clan structures and practices.

The participants in this study were descendants from these early settlers. Their parents and grandparents brought with them their cultures and values, which they had absorbed in their homeland of Scotland. These included strong family ties, land succession within the family, Protestant work ethic with a strong Presbyterian church membership and 'first footing' 'tin canning' and other social practices. Even the food eaten, porridge for breakfast, often with a sprinkling of salt, was a common practice among the older members of Tuatapere families. A pipe band was formed and highland dancing taught and continues to this day.

These beliefs and practices were explored during the study interviews. The findings showed that the sharing of these beliefs and the dependence on each other and the implications of this within the rural surrounding creates a community spirit which binds the community together. Howden (2001), in her study on rural communities' perceptions and experiences of 'community' conducted in southern Southland, found that rural New Zealanders are parochial and retain traditional values and roles. This is a trait within a rural culture.

The family farm helped to maintain the historic structures and beliefs. Land succession was viewed as an important process in farming families. 'I went straight on to the farm when I left school and I stayed there 60 years ... We moved from there in 1954 and came back to the mother's original home ... We married in 1973 and returned to the farm and been there ever since' (Smith, 2009, p.56). The couples who owned the generational family farm and had to sell were often shunned by other family members. They had to carry the guilt of not only losing an asset for their own immediate family but losing part of the past for their extended family (Christie, 1991).

Change occurred more rapidly in the technological field with modernisation of farm equipment than it did in people's values and relationships. 'As each farm passed from generation to generation links between families in the country were maintained' (Pitt, 1998, p.47). However, with the economic changes of the 1980s many of these generational farms were sold and communities dispersed and the old connections broken. With these changes, new ways of operating came into being and introduced new thoughts into the established belief systems of the people. The impact of economic and social changes was evident in listening to the stories and reflections on the changing times, on those who remain as rural dwellers (Smith, 2009). 


\section{Influences that maintain the rural culture ethos}

\section{A gendered culture}

One of the main influences that was embedded in the rural community's culture was the division of roles based on gender. This had its base when the male was the physical worker on the land and financial decision maker, and the woman was the housekeeper and the caregiver of children (Phillips, 1996; Allan, 2006). The women in the study had clear views about the division of roles.

Mum was always involved in one thing, Women's Division. In her latter life (after father died) she was very active in her own right. Up until then she was a shadow of Dad's ... I believe a lot of the women were subservient. They were pleased to stay at home on the farm and the only thing they had to worry about was making scones when the stock agent came ... that wasn't enough for me and I think that was one of the reasons my marriage didn't survive (Smith, 2009, p.85).

With the economic downturn in the 1980s many women had to enter the paid workforce and, along with other influences impacting on society's attitudes at the time, male and female roles changed. With the older participants in the study some of the old attitudes still remained, but for others there was a clear understanding of changing roles in society.

\section{A family culture}

The family participating in social activities together was a common theme from all the participants. The attendance at local functions and social activities was always a whole family affair. 'When I was a child you went to the Tuatapere Sports. The whole family went ... Now days it is not the same as a sit down family thing. Things are a lot faster' (Smith, 2009, p.62). However the participants of the study spoke of family values and expectations still being held and expected within the community.

\section{A community-based culture}

This sense of self that related to their self-worth extended into how they integrated into the community. One of the strong values and beliefs of the rural culture is that one must become part of the community and contribute to its existence. This means being visible in social activities and volunteering wherever possible.

Howden (2001) found that a sense of community depended on whether one was a newcomer to the district or a local born and bred. From her study she found that the locals saw community as something that brought them together, which might be their restricted physical location, whereas the newcomers to the district saw it mainly as a connection to social groups. In the Tuatapere study the residents saw the ability to volunteer as a community responsibility, gave a sense of belonging, an identity, as well as something that helped them to survive. One participant stated, 'Tuatapere was built on volunteerism, if there is such a word,' (Smith, 2009, p.56). Another participant explained:

There is a perseverance and I think he (father) instilled in me from a very early age his love of the community and people. Realising that other people could offer something and being able to draw on that ... It was being part of a team, taking people along with you (Smith, 2009, p.61). 
They had an expectation that those who came into the district would embrace this ethos and likewise contribute to the community on a voluntary basis. Sometimes this did not happen. With the downturn in sheep farming caused by the removal of subsidies in the late 1980s, many family sheep farms were sold. These were purchased over the ensuing years by both private individuals and companies and converted into dairy farms. Southland is still experiencing this phenomenon, and although it also occurs in other parts of rural New Zealand, it has greatly changed the face of rural Southland.

There is still debate and discussion over the change in the landscape of the countryside, large dairy sheds, under-road accesses, removal of trees, and effluent discharge into the streams and rivers, which are all features of the new dairy farming industry. The employment of migrant workers, mainly from the Philippines, created challenges to the communities with the 'insiders' and 'outsiders' way of thinking occurring.

Another aspect of newcomers is that the community can experience or perceive an overall fall in social capital if social networks and levels of volunteering decline. Sometimes this can be a perceived problem as newcomers have yet to develop their own networks and systems of support (Taylor, Taylor, \& McCall, 2009, p.21).

When volunteering didn't occur due to work commitments, or feelings of inadequacy or non-acceptance, then the longer-term residents viewed this as detrimental to the community's wellbeing. 'Well I don't think it is the same now. People have moved in and things have changed. People do not give up their time as willingly and as freely as they did in those days,' (Smith, 2009, p.56). They also expected the younger residents to contribute and look outwards to the needs of others rather than focusing on themselves.

\section{Culture from a young person's perspective}

Young people in rural communities are influenced by how they view themselves in relation to how strong their social connections are. Three quarters of the young people interviewed in a Western Southland study stated that they take part in sport and/or activities outside of school. When asked why they choose to do physical activities the main responses were, 'fun, opportunity to socialise, because they are good at it and like competing.' However they highlighted the lack of accessibility to social venues and the excitement thereof.

The young people from Western Southland reported that they like to frequent places that attract other young people ... however most indicate that there is a lack of accessible places and facilities to spend time ... Young people's perceptions of appropriate, interesting venues for them determines if they feel safe enough to engage and participate in the activities and then feel engaged and attached to their community (Venture Southland-Western Southland Youth Needs Analysis, 2009, pp.36-37).

The young people's need for social interaction and the difficulties they encounter due to sparseness of population and physical isolation creates an even stronger dependence on each other. Their social interaction is mainly through sporting groups or other organised group activities. This gives them an identity that is often related to their sporting endeavours and their rural environment. This is not just identified by the younger people but also by their elders. Strong group identity, relating to their particular rural area, secures their sense of belonging and contributes to the social culture. This however can be isolating for those who are not sports minded and, due to their isolation, do not have other fields of interest 
to pursue. Further research is required to explore the effects of this on rural communities and how it impacts on their sense of rural culture.

\section{External influences on the community}

The community living with these cultural expectations, both young and old, is affected by what happens within their environment and by decisions made by policy makers at a local and national level. Maidment and Bay (2012), state that to practice social work in a rural community one must consider the location-specific history, the cultural norms and also events that occur that impact on the people.

Those in the Tuatapere study were hit by a flood in 1984. The river that flows through the town burst its banks and flooded through many low-lying houses and property. The supportive environment and volunteering attribute came to the fore. 'I went down the Half Mile assisting old women and their cats out of their houses. By the time I got back the water was up to my waist. No-one was hurt. They all got out' (Smith, 2009, p.62). Fortunately there was no significant relocation out of the area due to the flood as most people rebuilt their existing properties.

Changes within the health and education services over the years saw different provisions for services. This affected the local schooling, medical and maternity services and so new initiatives had to be found to provide for the community's needs.

As well as changes in farming practices, the restructuring of the Forest Service within the 1980s had a dramatic effect on this community. People had to relocate to find new employment. This affected the businesses within the township and many closed.

Then in 1987 at the same time as the sharemarket crash, the Government drew a line through native logging and that was the demise of Tuatapere ... It ruined the town and then all our young people up and left and went further afield and haven't come back (Smith 2009, p.58).

It was stated by one interviewee that it also took a level of expertise that had existed within the clerical personnel of the Forest Service. These people were invaluable, contributing their skills on school and other such committees. All these changes impacted on the people and they had to combine their efforts to find solutions.

\section{Community response using their cultural strengths}

Due to these external influences the people looked to themselves and pooled their resources to meet their challenges. The rural culture qualities of resilience, parochialism, community spirit and self determination came to the fore. They used their initiative, created new industries and then sought funding to meet these needs.

We got the whole building for a dollar ... so that was the Hospital Trust ... Then we started the Medical Trust. We bought the medical practice ... That's why the Hump Track came about ... I have never seen so many people volunteer ... people were standing up from the main body of the floor saying I want to be part of this ... It was the most thrilling meeting I have ever been to because the atmosphere was electric (Smith, 2009, p.69).

The resilience passed down from their parents, as well as that developed from their own life experiences and hardships, together with the collegial support, enabled them to survive 
and determinedly stay focused on their goals. The results continue to be both rewarding and challenging. 'As far as community goes I've been a community person most of my life. I sort of liked to help out in the community as much as I could' (Smith, 2009, p.63).

These experiences of turning to each other for solutions, exploring and trying out options, created resilience and an independence that added to the already developed view of themselves and others, thereby building on the existing characteristics of a rural culture.

\section{Social work practice}

\section{Awareness of a rural culture}

Social workers entering a rural environment need to have an awareness of the aforementioned facts. They need to have an awareness of who they are themselves and then an awareness of the people with whom they are going to work. Being sensitive to a person's culture and lifestyle is one of the main requirements of a social worker. This is particularly necessary when working within small populations such as rural areas (Locke \& Winship, 2005). There is usually an initial reluctance to newcomers and the worker has to establish their credibility that relates more to their character than their profession.

If one has not been brought up in a rural community then you will never truly understand the nuances and thoughts of your families. Often rural people do not know themselves that what they think and do naturally is not shared by urban dwellers. Casting one's eye to the directions to determine weather, or surveying the mountains to likewise determine weather, glancing at the sun for time of day, anticipating stock movement when walking amongst them, ensuring food usage and storage is monitored due to the distance to travel to purchase more, are just some of the minor but daily subconscious awarenesses that rural people have developed. For those who come from an urban background to live in this environment it can be very lonely and confusing.

The historical influences and cultural expectations of the community need to be understood. These will work both positively and negatively with or against the worker and the families. 'It is essential to work in the community in a way that is respectful of its norms and traditions and to be sensitive to how the future is viewed if efforts at change are to be effective' (Locke \& Winship, 2005, p.7).

In rural communities time is often driven by the seasons of the year and the functions that need to be carried out either on the farm or rural business. 'Rural areas are traditionally tied to the land and rhythms of nature' (Locke \& Winship, 2005, p.9). A social worker needs to have an awareness of this and plan their contact around these occasions.

The issue of dual relationships also needs to be considered. The social worker may already be known within the community as a family member, so confidentiality needs to be considered carefully in consultation with the client. Roles need to be clarified and options for meetings and visits carefully discussed and planned.

Just as tangata whenua should have choices as to whom they engage as their social worker, so should families within rural communities have the choice. The need therefore to ensure that local services are available for local people is very important. 
I believe we can help ourselves if they let us. We are so bound by this Resource Management Act ... Southland District Council all live in the Invercargill council area and our rates don't impact on them. If they were actually being affected by the policies that were being set down

... then it would be different (Smith, 2009, p.68).

\section{Methods of practice}

What method of practice should one use when working with rural families? As evident from the studies conducted with the Western Southland families, systems theory and strengthbased models fit within their knowledge of the world: systems theories because their sense of self within the community and the relationships they form are important to them; and strength-based as their life experiences have created a resilience that has helped them to survive. Their resilience will be the strength that the worker can harness to work with.

Using a strength based practice model is particularly relevant in a rural context, where clients already have a history of honouring strength and resilience and are most likely to relate to a 'can do' philosophy (Maidment, 2012, p.81).

The importance of volunteering and giving of oneself leads to their heightened sense of other systems that impact on their wellbeing as a community. Maidment and Bay (2012, p.223) promote using a place-based method of practice. 'Place means location and also the values, meaning and identity associated with that location.' An awareness of this 'place' within their environment is what creates their sense of a rural culture. Therefore the worker should work with the community utilising all inhabitants' knowledge and strengths to look at solutions not only for the individual but for the group as a whole.

\section{Application of practice with rural families}

How do we meet the needs of our rural families using these identified models of practice? Firstly the social worker should be aware that resistance to change may be an obstacle and alienation amongst the old and young and newcomers to the area, need to be considered. Practice Standard 3 of Aotearoa New Zealand Association of Social Workers, the professional body of social workers, states 'establishes an appropriate and purposeful working relationship with clients, taking into account individual differences and the cultural and social context of the client's situation' (ANZASW, 2008, p.14).

The individual social worker can ensure they carry out all the previously stated practice but it can be very difficult without the support of their agencies and the Government. Social responsibility needs to be introduced into policy decision making. It is not just about funding but the effect of decisions on local communities. At present the funding for services is driven by Government expectations rather than by 'bottom-up' initiatives of the community. Social workers find 'the challenge is for organisations to maintain the links with their original vision and with their communities, creating space for those communities to voice dissent or provide input on programme direction or content' (Aimers \& Walker, 2011, p.48). Therefore the rural community's needs must fit with their own ideas not imposed by Government-led initiatives with the resulting often cumbersome accountability methods. The communities should not be trying to fit their needs within a dictated funding bucket.

Social work in New Zealand at present is led by the demand for funding and therefore practice dictated by Government-expected outcomes. This is described as a State-driven (top down) development rather than needs driven from the community (bottom up) (Aimers 
\& Walker, 2011, p.38). This is to the detriment of the families being worked with and their expressed needs that are identified to social workers.

It is difficult to quantify social work and the efforts to do so are often counterproductive to the clients' needs. Some of the social worker's time is spent recording data for funding and contractual obligations, when this time could be spent working with the families. The worker needs to balance the need to 'secure the client's participation in the working relationship,' assisting them 'to gain control over their own circumstances,' within the 'systems of accountability in respect of the agency, clients and the social work profession' (ANZASW, 2008, pp. 15-17). This accountability can be weighted toward the worker imposing unnecessary questions on their families to fulfill funding criteria. The social worker's role is to see that 'the organisations and systems, which are part of the social work effort, are responsive to the needs of those who use them' (ANZASW, 2008, p.17).

Shannon and Young (2004, p.280) propose an alternative viewpoint to the hierarchies and dominating control of residualism, the expert professionalism of institutionalism, and the potential for divisive and conflicting positions of collectivist theory' by an alternative change strategy. This interactive, sharing relationship brings the working partnership to an equal basis where the worker respects and has knowledge of the person and they in return accept and respect the contributions of the worker. In other words 'Put on your gumboots and walk with me!'

As shown in the Tuatapere study, the people within the community worked hard to sustain a level of living that kept them economically viable. Within these efforts their values, beliefs and shared view of the world enabled them to work together mainly on a voluntary basis to achieve their end goal. This sustainability is what a social worker has to appreciate and therefore if entering this environment needs to understand how it was established and how it works.

\section{Conclusion}

Rural New Zealand has it own uniqueness and its own culture. Decisions made for urban New Zealanders may be as removed from the realities of their rural cousins as one living within another ethnic community. Social workers in rural communities need to be assessed and employed on the basis of how they will be accepted within the community. They then need to have the support of each other and their professional body to carry out the 10 practice standards within which they work.

In Aotearoa New Zealand there have been various attempts to establish a rural social work network. These exist informally in various areas but not to my knowledge at a national level. A voice from the hinterland, affirming their presence and an acknowledgement of their issues, is very necessary. Support for rural workers is imperative as the issues that they encounter are particular to their area of work.

Finally, when you predict the weather by viewing the mountains, that is rural. When you tell the time of day by the sun, that is rural. When you can identify birdsong and investigate when there is a strange sound, that is rural. When you are comfortable with isolation, that 
is rural. When you can run through the paddocks barefooted and subconsciously avoid thistles and fresh animal droppings, that is rural. When you want to include these facts in a social work journal, that is rural culture. Och aye!

\section{References}

Aimers, J., \& Walker, P. (2011). Incorporating community development into social work practice within the neoliberal environment. Aotearoa New Zealand Social Work Journal, XXIII(3), 38-49.

Allan, J.K. (2006). Integrating life, work and identity: Farm women transforming 'self' through personal struggle and conflict. In S. Bellet, T. Fenwick and M. Somerville (Eds). Work, subjectivity and learning. Dordrecht: Springer.

ANZASW, (2008). Competency handbook: Practice standards. Christchurch: Toltech Print.

Chile, L. (2004). Good practice in community development work: Towards community well-being. Aotearoa New Zealand Social Work Journal, XVI(3), 26-31.

Chalmers, A.I., \& Joseph, A.E. (1995). Growing old in place: A view from Rural New Zealand. Health $\mathcal{E}$ Place, 1(2), 79-90.

Christie, R.G. (1991). Leaving the land: Case studies of farming families who left Southland farms between 1987 and 1989. Christchurch: Rural Ministry Unit.

Connolly, M., Crighton-Hill. Y., \& Ward, T. (2006). Culture and child protection reflexive responses. London: Jessica Kingsley Publishers.

Cormack. S., \& Orwin, J. (1997). Four generations from Maoridom. Dunedin: University of Otago Press.

Howden, S.I. (2001). Rural communities: Expressions of 'community' in context: Narratives from the Lower Mataura Valley in Southland. Unpublished master's thesis. Palmerston North: Massey University.

James, B., \& Saville-Smith, K. (1989). Gender, culture E power. Auckland: Oxford University Press.

Jones, G. (1984). Working class culture and working class politics in London, 1780-1900. Journal of Social History, 7, 460-507.

Locke, B.L., \& Winship, J. (2005). Social work in rural America: Lessons from the past and trends for the future. In N. Lohmann \& R. A. Lohmann (Eds). Rural social work practice (pp. 3-24). New York: Columbia University Press.

Maidment, J. (2012). Understanding rurality: A conceptual framework. In J. Maidment \& U. Bay (Eds). Social work in rural Australia. Enabling practice (pp. 3-18). Sydney: Allen \& Unwin.

Maidment, J. (2012). Developing new approaches to mental health in farm settings. In J. Maidment \& U. Bay (Eds). Social work in rural Australia. Enabling practice (pp. 75-89). Sydney: Allen \& Unwin.

Maidment, J. \& Bay, U. (2012). Rural practice: An agenda for the future. In J. Maidment \& U. Bay (Eds). Social work in rural Australia. Enabling practice (pp. 221-234). Sydney: Allen \& Unwin.

Miller, F.W.G. (1975). West to the Fiords. Christchurch: Whitcoulls.

Phillips, J. (1996). A man's country? The image of the pakeha male - a history. Auckland; Penguin Books.

Pitt, L. M. (1998). Patriarchs, paddocks and the personal: Five women from the Wharehuia/Te Popo district talk about their lives. Unpublished master's thesis. Palmerston North: Massey University.

Pitt, L. (2010). Woolsheds, wet weather gear and the West Coast: Social work practice in Taranaki. Aotearoa New Zealand Social Work, 22(3), 39-47.

Shannon, P., \& Young, S. (2004). Solving social problems: Southern perspectives. Victoria: Dunmore Press.

Smith, P.A. (2009). Whatever happened to Tuatapere: Are we doing very nicely thank you? Unpublished master's thesis. Palmerston North: Massey University.

Sullivan, T., \& Thompson, K. (1984). Sociology, concepts, issues and applications. New York: John Wiley and Sons.

Taylor, N., Taylor C., \& McCall R., (2009). Going the extra mile ... meeting future needs in Western Southland. Christchurch: Taylor, Baines \& Associates.

Venture Southland. (2009). Western Southland youth needs analysis. Invercargill: Venture Southland. 